\title{
Phycomycosis of the bronchus
}

\author{
R. M. WINSTON \\ From Hope Hospital, Salford, Lancashire
}

SYNOPSIS A case of phycomycosis of the bronchus in a 29-year-old diabetic man is reported. The interval between infection and death was not less than 35 days. Infection of the bronchus appears to have been direct. The diagnosis of phycomycosis could have been made before death.

Phycomycosis is rare; references to all the reported cases have been given by Symmers (1962), Baker, Seabury, and Schneidau (1962), La Touche, Sutherland, and Telling (1963), Burkitt, Wilson, and Jeliffe (1964), and Mukerji (1964), but is probably more common than the few reports suggest (Symmers, 1962). Four cases have been reported in the United Kingdom, one from Worcester (Kurrein, 1954), two from London (Symmers, 1962), and one from Leeds (La Touche et al., 1963). A fifth case from the United Kingdom is reported in this article.

\section{CASE REPORT}

The patient, an Irishman aged 29, lodged in Stretford near Manchester. In January 1963, according to his landlord, he began to be nervy and breathless. His health steadily deteriorated and he was admitted to hospital on 9 May 1963. Diabetes mellitus with marked ketosis was diagnosed and rapidly controlled and other abnormalities were investigated and treated concurrently. Twenty-two teeth were extracted on account of pyorrhoea. A severe stomatitis yielded Candida albicans on culture and cleared with oral nystatin. A radiograph of the chest on 10 May showed some increase in the size of the right hilar shadow with slightly increased shadowing extending into the right lung field, and this picture was unchanged six days later. No acid-fast bacilli were found in six specimens of sputa and two of faeces. Two sputa were negative for tuberculosis on culture. Bronchoscopy was performed on 27 May and the right main bronchus was found to be partly blocked by what looked like sloughing mucosa. A portion of this slough was removed and reported to be a grey, sludge-like material with many small islands of pus cells, together with some tissue fragments covered by regular squamous or pseudostratified epithelium. The deeper tissues showed heavy infiltration with mixed inflammatory cells and were congested. Greatly improved in health and stabilized on morning and evening doses of insulin, he was discharged from hospital on 4 June. There is some doubt whether he continued to take both daily doses but his health remained good. On 13 June 1963 he died suddenly; his death was

Received for publication 23 March 1965. reported to H.M. Coroner, and the body was refrigerated and a post-mortem examination made 22 hours after death.

Death was clearly due to haemorrhage from a lesion of the right main bronchus and adjacent pulmonary artery. No abnormalities other than this local lesion and haemorrhage were found. The right main bronchus was almost completely blocked by a soft greyish-purple mass. On section an approximately spherical, unencapsulated mass, approximately $1 \frac{1}{2} \mathrm{~cm}$. in diameter, was found infiltrating the bronchus and pulmonary artery. No cultures were prepared.

Microscopy showed that the lesion seen at necropsy was an ischaemic infarct of the bronchus and pulmonary artery surrounded by a narrow zone of polymorph infiltration, surrounded in turn by a broad zone of more chronic inflammation. Rupture had occurred at the edge of the infarct and here there was some fibrosis. Hyphae were plentiful in the infarct (Figs. 1 to 3 ) and in the zone of polymorph infiltration. They were thin-walled, rarely septate and irregular, varying in diameter from $2 \mu$ to $24 \mu$. Branching was irregular. Contrast was excellent with iron haematoxylin but poor with alum haematoxylin. The hyphae were periodic-acid-Schiff and Gramnegative and did not stain with silver. Vascular invasion was prominent in the infarct and nerve was infiltrated, but cartilage was not invaded. In contrast to the infarct, hyphae were very scanty in the broad zone of more chronic inflammation and were found only as small fragments in granulomas. These consisted of a small, central mass of pus surrounded by epithelioid cells and giant cells and hyphae were found in the pus, among the epithelioid cells (Fig. 4) and in the giant cells. Lung and bronchial lymph nodes were included in the tissues examined. There was a mild inflammatory reaction in the lung but little reaction in the lymph nodes. No hyphae were found in the lung and there was no infiltration of lymphatics or lymph nodes by hyphae.

In view of these findings the tissue removed at bronchoscopy was reviewed and the original histological report was confirmed. The surgeon had apparently removed inflamed bronchus adjacent to the infarct. The paraffin block was then serially sectioned and deep in it a tiny fragment of necrotic tissue was found infiltrated by hyphae identical with the hyphae found at necropsy (Fig. 5). Also, a dense mycelium was found in pus in the 


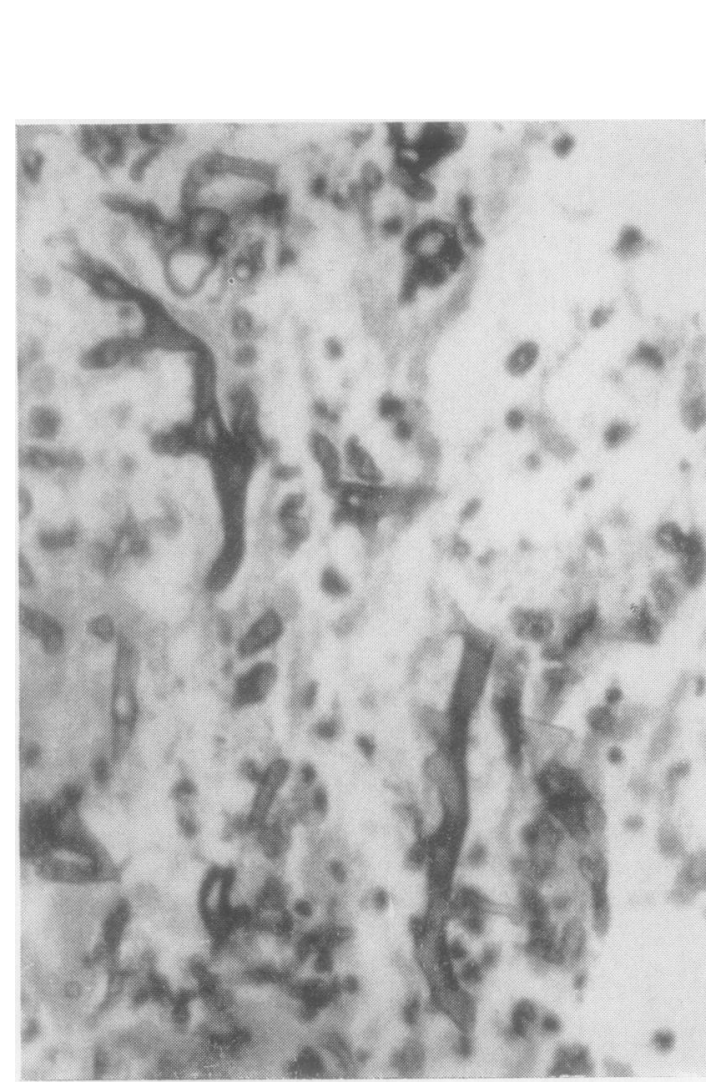

FIG. 1.

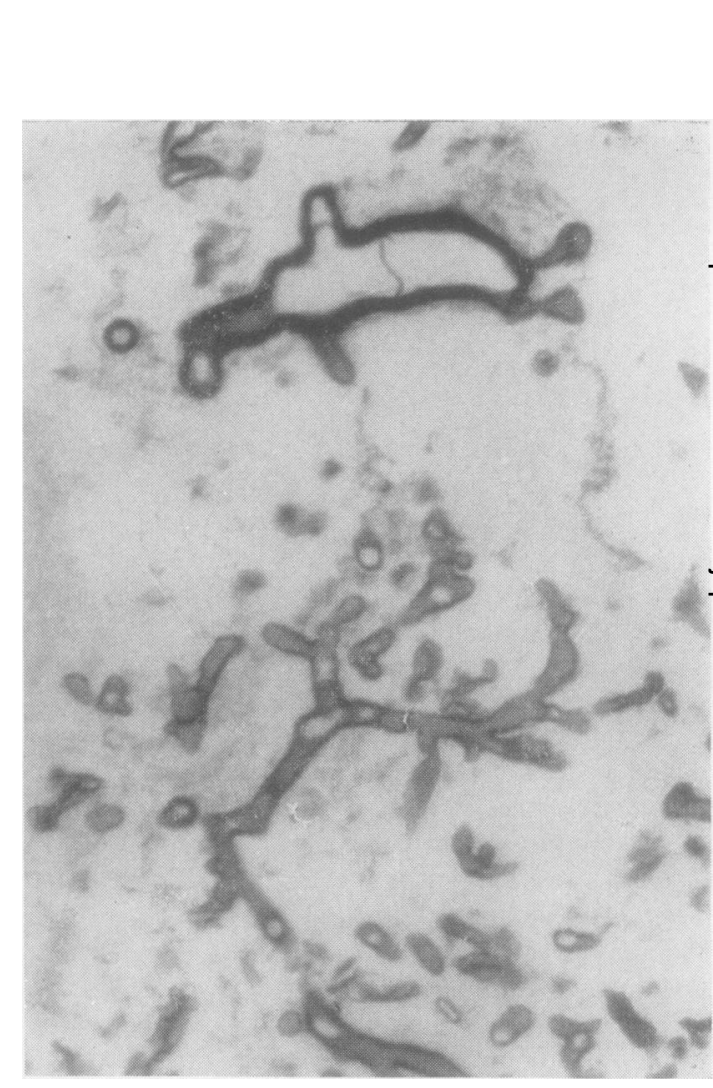

FIG. 2.

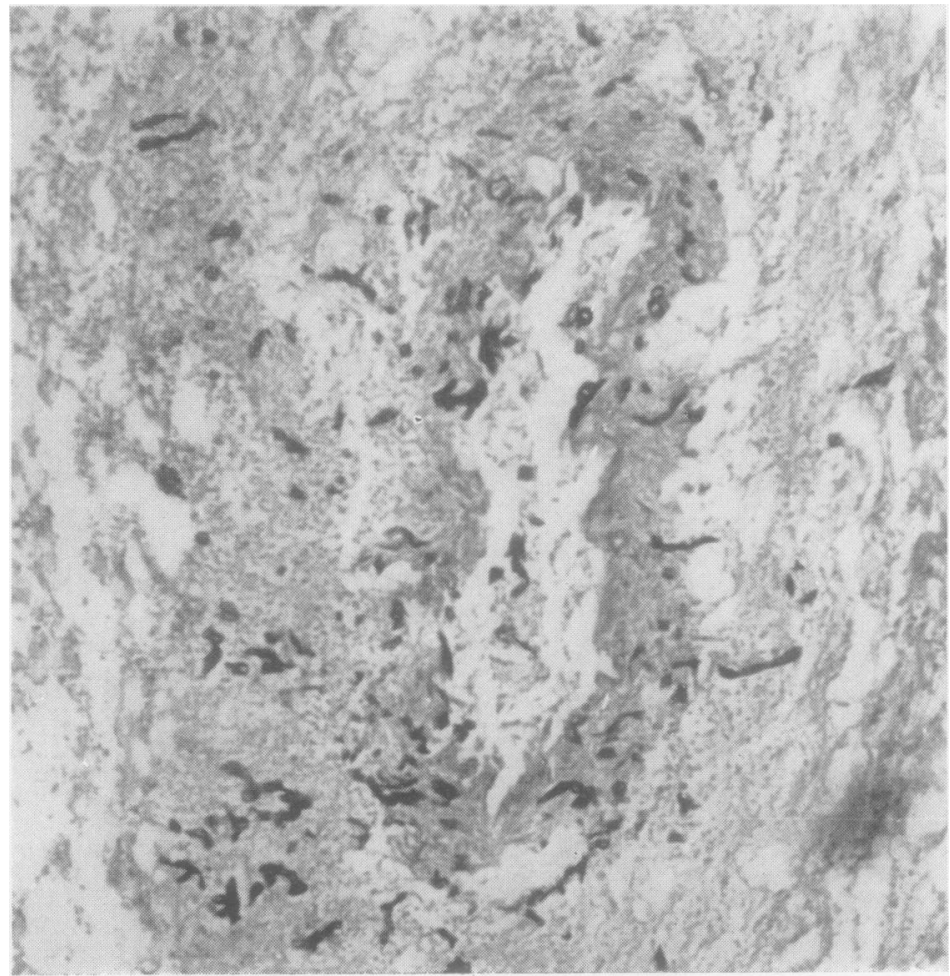

FIG. 1. Bronchial infarct with typical phycomycete hyphae. Iron haematoxylin and eosin $\times 400$.

FIG. 2. Bronchial infarct with typical phycomycete hyphae. Iron haematoxylin and eosin $\times 400$.

FIG. 3. Phycomycete infiltrating an infarcted blood vessel. Iron haematoxylin and eosin $\times 100$.

FIG. 3. 


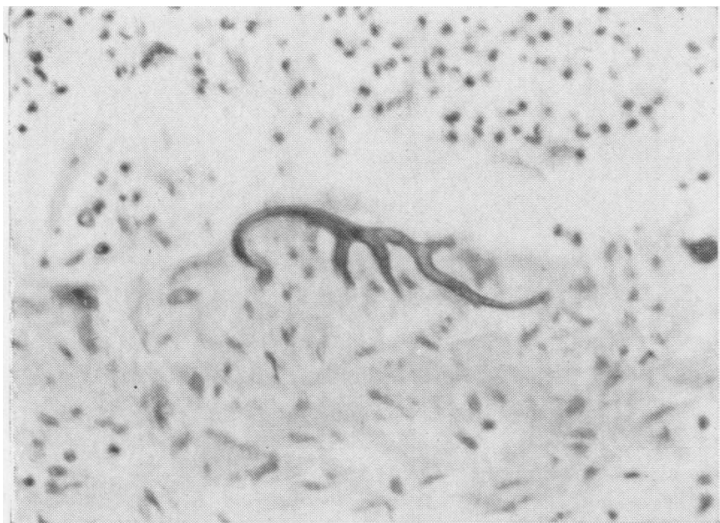

FIG. 4. Hypha among epitheloid cells. Iron haematoxylin and eosin $\times 400$.

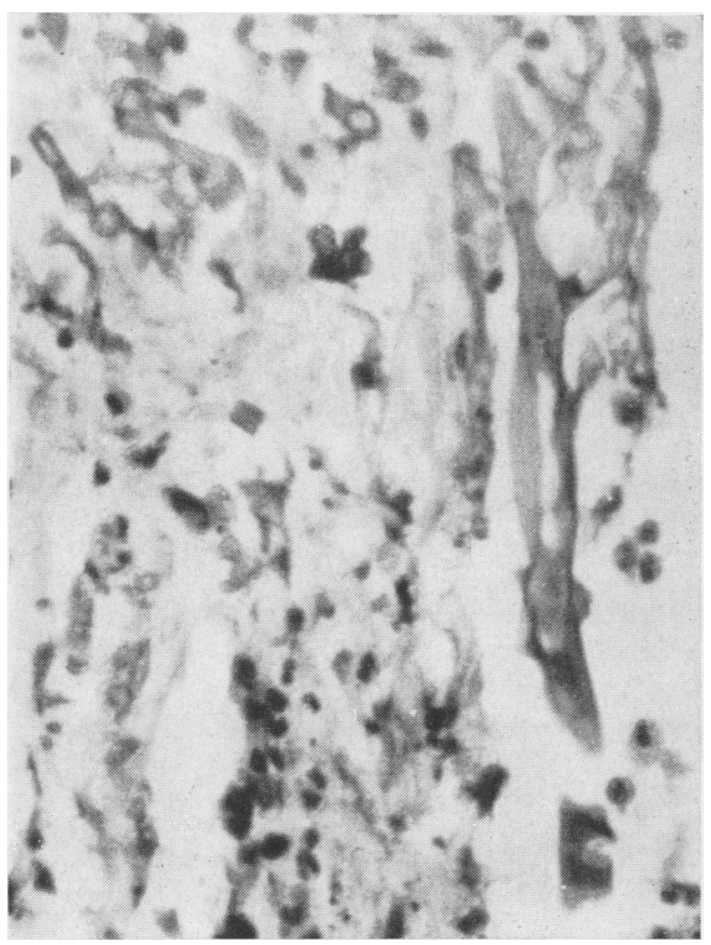

FIG. 5. Phycomycete in bronchial tissue removed during life. Iron haematoxylin and eosin $\times 400$.

bronchial lumen. The hyphae forming the mycelium resembled those found in the infarct, except that they were narrower and septate, though, on examination at a magnification of $\times 1,250$, many of the septae were found to be false and due to collapse and folding.

No fruiting bodies were found in 163 sestions.

\section{COMMENT}

The fungus other than the dense mycelium found in the bronchial lumen is identified as a phycomycete because it fits the criteria given by Emmons, Binford, and Utz (1963). More detailed identification is impossible in the absence of fruiting bodies. It is considered to be a pathogen and not a post-mortem invader because hyphae were found in granulomas around the infarct and in giant cells. The association of phycomycosis with diabetes mellitus is well known and needs no comment.

How this patient came to be infected is not known. $\mathrm{He}$ was not infected by his surgeon, because the characteristic hyphae were found in the tissue removed at bronchoscopy. This tissue and the chest radiograph taken on the day after admission to hospital strongly suggest that he was infected before admission, and therefore the interval between infection and death cannot have been less than 35 days.

The histological findings in this case are those of visceral phycomycosis and not those of the dermal type. However, it cannot be classified with any of the three main clinical types of the visceral disease - pulmonary, rhinocerebral, and alimentary. In the pulmonary type it is assumed that infection is caused by inhalation of spores and bronchial involvement occurs by direct extension of a lung lesion. In the case described here no evidence of any pre-existing lesion of lung or bronchus was found and infection of the bronchus appears to have been direct.

In a section taken through the edge of the rupture of the pulmonary artery some fibrosis was found. Before the final, fatal haemorrhage there must have been some leakage of blood, and bronchial phycomycosis, therefore, must be considered to be a possible cause of haemoptysis.

The dense, septate mycelium found in the pus in the bronchial lumen before death has not been identified. Either it is the same phycomycete as was found in the infarct or a double mycotic infection was present. Phycomycetes in tissue are not without septae but rarely septate, and it is possible that when a phycomycete grows in the peculiar medium of pus in the bronchus of a diabetic it may develop more septae that it does when it invades tissue.

The diagnosis could have been made before death from the tissue removed at bronchoscopy.

\section{REFERENCES}

Baker, R. D., Seabury, J. H., and Schneidau, J. D., Jr. (1962). Lab. Invest., 11, 1091.

Burkitt, D. P., Wilson, A. M. M., and Jelliffe, D. B. (1964). Brit. med. J., 1, 1669.

Emmons, C. W., Binford, C. H., and Utz, J. P. (1963). Medical Mycology, P. 185. Kimpton, London.

Kurrein, F. (1954). J. clin. Path., 7, 141

La Touche, C. J., Sutherland, T. W., and Telling, M. (1963). Lancet, 2, 811.

Mukerji, S. (1964). Brit. med. J., 2, 1009.

Symmers, W. St. C. (1962). Lab. Invest., 11, 1073. 